Греца С.М. Податкова застава як спосіб забезпечення виконання конституційного обов'язку зі сплати податків...

DOI: $10.36695 / 2219-5521.4 .2020 .15$

УДК 342: 336.22

\title{
C.М. ГРЕЦА
}

Світлана Михайлівна Греца, кандидат юридичних наук, доцент Ужгородського національного університету*

ORCID: 0000-0002-9174-7454

\section{ПОДАТКОВА ЗАСТАВА ЯК СПОСІБ ЗАБЕЗПЕЧЕННЯ ВИКОНАННЯ КОНСТИТУЦІЙНОГО ОБОВ'ЯЗКУ ЗІ СПЛАТИ ПОДАТКІВ І ЗБОРІВ}

Постановка проблеми. У системі конституційних обов'язків важливе місце займає обов'язок сплачувати податки і збори в порядку і розмірах, встановлених законом, який встановлений ст. 67 Конституції України.

Як слушно зазначає О. Білоскурська, людина, перебуваючи в суспільстві, постійно взаємодіє з іншими людьми, а тому вона не може не мати обов'язків стосовно суспільства, інших осіб, держави і не може відмовитися від виконання своїх конституційних обов'язків, передусім тому, що вони виступають засобом забезпечення конституційних прав і свобод. Невиконання своїх обов'язків окремими суб' єктами суспільства призводить до обмеження прав і свобод інших суб'єктів суспільства, що, в свою чергу, створює умови для виникнення суттєвих непорозумінь між людьми ${ }^{1}$.

Дійсно, невиконання або неналежне виконання обов'язків зі сплати податків та зборів призводить до дисбалансу суспільних та приватних інтересів, створює ризики неможливості повноцінного виконання державою своїх завдань та функцій, порушення прав та законних інтересів суб'єктів, які мають право на бюджетне фінансування.

Проблеми виконання конституційних обов'язків є предметом наукових досліджень українських і зарубіжних вчених. Однак порівняно з дослідженням забезпечення реалізації прав людини їм приділяється значно менша увага. Водночас належне виконання конституційного обов'язку зі сплати податків і зборів має надзвичайно важливе значення для суспільства, тому дослідження способів забезпечення виконання цього обов'язку на сьогодні залишається одним із найбільш актуальних у теорії податкового права.

Аналіз останніх досліджень і публікацій. Вивченню даного питання було присвячено чимало праць та наукових досліджень загальнотеоретичного фінансово-правового характеру, серед яких слід відмітити роботи Д.М. Белова, Ю.М. Бисаги, Я.В. Греци, М.П. Кучерявенка, Т.А. Латковської, О.П. Орлюк, Л.А. Орлюк, Н.Я. Якимчук.

Формулювання мети статті. Метою даного дослідження є визначення правових аспектів та особливостей застосування такого способу забезпечення виконання конституційного обов'язку зі сплати податків і зборів, як податкова застава.

Виклад основного матеріалу. Виконання обов'язку зі сплати податків і зборів грунтується на кількох факторах, серед яких слід виділити такі: 1) наявність системи законодавства, що встановлює правові засади податкової системи держави, механізм сплати податків, права та обов'язки суб' єктів податкових правовідносин; 2) рівень податкової культури та податкової дисципліни платника податків; 3) потенційна можливість застосування державного примусу в разі порушення норм податкового законодавства 2 .

Виконання платниками податків та іншими суб'єктами податкового обов'язку об'єктивно не може спиратися лише на високий рівень їх правової культури і усвідомлення суспільної значущості передбаченої нормами податкового права належної поведінки. У сучасних умовах для забезпечення необхідного рівня податкових надходжень великого значення набуває застосування заходів державного примусу3.

Однією із визначальних ознак податку є його обов'язковість. Норми податкового законодавства передбачають юридичну відповідальність у разі невиконання або неналежного виконання податкового обов'язку.

Виконання конституційного обов'язку, передбаченого ст. 67 Конституції України, реалізується сплатою кожним податків і зборів. Встановлення системи оподаткування, податків і зборів, їх розмірів та порядку сплати є виключно прерогативою закону. При унормуванні цих суспільних відносин держава має право визначати механізми, які забезпечують платником належну сплату податків і зборів.

М.П. Кучерявенко, визначаючи способи забезпечення виконання обов'язку зі сплати податків, називає серед них такі, як податкова застава, пеня і адміністративний арешт майна платника податків ${ }^{4}$.

Одним із способів такого забезпечення є інститут податкової застави. Вперше він був запроваджений в Україні Указом Президента України «Про заходи щодо підвищення відповідальності за розрахунки з бюджетами та державними цільовими фондами» від 4 березня 1998 р. Закріплення на рівні закону інститут податкової застави набув з прийняттям Закону України «Про порядок погашення зобов'язань платників податків

(C) С.М. Греца, 2020

* Svitlana Hretsa, Ph.D. in Law, Associate Professor of Uzhhorod National University 
перед бюджетами та державними цільовими фондами». У подальшому він знайшов своє відображення в нормах Податкового кодексу України.

Податкова застава - спосіб забезпечення сплати платником податків грошового зобов'язання та пені, не сплачених таким платником у строк, визначений законом. У разі невиконання платником податків грошового зобов'язання, забезпеченого податковою заставою, податковий орган звертає стягнення на майно такого платника, що є предметом податкової застави.

Право податкової застави виникає згідно із законом та не потребує письмового оформлення. Разом 3 тим орган державної податкової служби зобов'язаний безоплатно зареєструвати податкову заставу у відповідному державному реєстрі 5 .

Право податкової застави виникає в разі несплати у строки, встановлені законом, суми грошового зобов'язання, самостійно визначеної платником податків у податковій декларації або визначеної контролюючим органом, з дня виникнення податкового боргу. Воно поширюється на будь-яке майно платника податків, яке перебуває в його власності (господарському підпорядкуванні або оперативному управлінні) у день виникнення такого права і балансова вартість якого відповідає сумі податкового боргу платника податків, а також на інше майно, на яке платник податків набуде прав власності в майбутньому. Згідно 3 п. 89.2 ст. 89 Податкового кодексу України у разі якщо балансова вартість такого майна не визначена, його опис здійснюється за результатами оцінки, яка проводиться відповідно до Закону України «Про оцінку майна, майнових прав та професійну оціночну діяльність в Україні».

Майно, на яке поширюється право податкової застави, оформляється актом опису. Для забезпечення належного виконання конституційного обов'язку зі сплати податків і зборів важливо, щоб до акта опису включалося ліквідне майно, яке можливо використати як реальне джерело погашення податкового боргу.

Законом передбачено, що керівник органу державної податкової служби за місцем реєстрації платника податків, який має податковий борг, призначає такому платнику податків податкового керуючого. Податковий керуючий описує майно платника податків, який має податковий борг, у податкову заставу, здійснює перевірку стану збереження майна, що перебуває в податковій заставі, проводить опис майна, на яке поширюється право податкової застави, для його продажу у випадках, передбачених законом, одержує від боржника інформацію про операції із заставленим майном, а в разі його відчуження без згоди органу державної податкової служби (за умови, коли наявність такої згоди має бути обов'язковою згідно з вимогами закону) вимагає пояснення від платника податків або його службових (посадових) осіб. У разі продажу в рахунок погашення податкового боргу майна платника податків, на яке поширюється право податкової застави, податковий керуючий має право отримувати від такого платника податків документи, що засвідчують право власності на зазначене майно.

Однією із дієвих гарантій забезпечення виконання податкового обов'язку, а також реалізації повноважень податкового керуючого є норма, яка передбачає, що у разі якщо платник податків не допускає податкового керуючого для здійснення опису майна такого платника податків у податкову заставу та/або не подає документів, необхідних для такого опису, податковий керуючий складає акт відмови платника податків від опису майна у податкову заставу. У такому випадку орган державної податкової служби звертається до суду щодо зупинення видаткових операцій на рахунках платника податків, заборону відчуження таким платником податків майна та зобов'язання такого платника податків допустити податкового керуючого для опису майна у податкову заставу. Крім того, до платника податків у такому випадку може бути застосований більш жорсткий захід податкового примусу - адміністративний арешт його майна.

Платник податків зберігає право користування майном, що перебуває в податковій заставі, якщо інше не передбачено законом. При цьому він може відчужувати таке майно тільки за згодою органу державної податкової служби, а також у разі, якщо орган державної податкової служби упродовж десяти днів 3 моменту отримання від платника податків відповідного звернення не надав такому платнику податків відповіді щодо надання (ненадання) згоди. Якщо в податковій заставі перебуває лише готова продукція, товари та товарні запаси, платник податків може відчужувати таке майно без згоди органу державної податкової служби за кошти за цінами, що не є меншими за звичайні, та за умови, що кошти від такого відчуження будуть направлені в повному обсязі в рахунок виплати заробітної плати, єдиного внеску на загальнообов'язкове державне соціальне страхування та/або погашення податкового боргу.

Майно платника податків звільняється з податкової застави $з$ дня:

1) отримання контролюючим органом підтвердження повного погашення суми податкового боргу та/або розстрочених (відстрочених) грошових зобов'язань і процентів за користування розстроченням (відстроченням) в установленому законодавством порядку;

2) визнання податкового боргу безнадійним;

3) набрання законної сили відповідним рішенням суду про припинення податкової застави у межах процедур, визначених законодавством з питань банкрутства;

4) отримання платником податків внаслідок проведення процедури адміністративного або судового оскарження або в інших випадках, передбачених законом, рішення відповідного органу про визнання протиправними та/або скасування раніше прийнятих рішень щодо нарахування суми грошового зобов'язання;

5) отримання платником податків згоди контролюючого органу на відчуження майна, що перебуває у податковій заставі6. 
Греца С.М. Податкова застава як спосіб забезпечення виконання конституційного обов'язку зі сплати податків...

Водночас слід наголосити, що реалізація права податкової застави, тобто його продаж податковим органом, може здійснюватися виключно у разі недостатності коштів у платника податків. Таким чином, спочатку податковий орган повинен вжити заходів щодо стягнення грошових коштів (які знаходяться на рахунках у банках або готівки), і тільки після цього він може вживати заходів щодо стягнення податкового боргу за рахунок майна. Необхідно врахувати, що як стягнення коштів, так і звернення стягнення на майно може бути реалізовано виключно за рішенням суду. Такий підхід у цілому узгоджується із нормами ст. 41 Конституції України, відповідно до якої ніхто не може бути протиправно позбавлений права власності. Право приватної власності є непорушним. Примусове відчуження об'єктів права приватної власності може бути застосоване лише як виняток з мотивів суспільної необхідності, на підставі і в порядку, встановлених законом, та за умови попереднього й повного відшкодування їх вартості. Примусове відчуження таких об'єктів 3 наступним повним відшкодуванням їх вартості допускається лише в умовах воєнного чи надзвичайного стану. Конфіскація майна може бути застосована виключно за рішенням суду у випадках, обсязі та порядку, встановлених законом.

Разом із тим, як свідчить практика розгляду податкових спорів, якщо податковий орган звертається 3 позовом про стягнення податкового боргу в загальному позовному провадженні, розгляд такого позову може зайняти тривалий час, а враховуючи необхідність пройти дві судові процедури (спочатку стягнення за рахунок коштів, а потім - за рахунок майна), ефективність такого способу забезпечення податкового обов'язку, як податкова застава, значно знижується. Часто такий тривалий процес не відповідає інтересам самого платника податків, адже протягом усього часу, аж до повного погашення податкового боргу, нараховується пеня за несвоєчасну сплату податків, що тільки збільшує заборгованість платника. Тому в нормах закону варто передбачити позасудовий механізм звернення стягнення на предмет податкової застави у випадках, коли платник податків дає згоду на це.

Висновки. Інститут податкової застави є одним із основних способів забезпечення виконання конституційного обов'язку зі сплати податків і зборів. Опис ліквідного майна і реєстрація права податкової застави у відповідному державному реєстрі унеможливлює зловживання з боку платника податків, відчуження майна 3 метою уникнення погашення податкового боргу. Звернення стягнення на майно, яке перебуває в податковій заставі, на підставі рішення суду, забезпечує конституційні гарантії захисту права власності платників податків. Разом із тим, для підвищення ефективності цього інституту у нормах податкового права слід передбачити механізм позасудового звернення стягнення на заставлене майно у випадках, коли платник податків дає на це письмову згоду. Також такий позасудовий механізм міг би застосовуватися в разі відстрочення або розстрочення виконання податкових зобов'язань (за умови невиконання платником податків своїх зобов'язань) і закріплюватися у відповідному договорі між платником податків та податковим органом.

1 Білоскурська О.В. Загальнотеоретичні дослідження конституційних обов'язків людини і громадянина в Україні на сучасному етапі розвитку правової держави. Юридичний вісник. 2010. № 1(14). С. 37-39.

2 Греца Я.В. Правові аспекти застосування податкової застави для забезпечення виконання податкових зобов'язань. Науковий вісник Ужгородського національного університету. Ужгород, 2008. Вип. 9. С. 425-429 (Серія «Право»).

3 Податкове право. навч. посіб. / Г.В. Бех, О.О. Дмитрик, Д.А. Кобильнік та ін. / за ред. проф. М.П. Кучерявенка. Київ: Юріком Інтер, 2003. 400 c.

4 Там само.

5 Греца Я.В., Ярема В.І., Бисага Ю.М., Сідак М.В. Податкове право: навч. посіб. Київ: Знання, 2012. 389 с.

6 Податковий кодекс України від 2.12.2010 року № 2755-VI. Голос України. 2010. № 229-230.

Резюме зоорів.

Греца С.М. Податкова застава як спосіб забезпечення виконання конституційного обов'язку зі сплати податків і

У статті висвітлюються правові аспекти застосування податкової застави як засобу забезпечення конституційного обов'язку зі сплати податків і зборів. Визначено місце обов'язку зі сплати податків у системі конституційних обов'язків. Розкрито основні способи забезпечення виконання податкового обов'язку. Дано визначення поняття податкової застави, розкрито історію становлення цього інституту в законодавстві України. Наведено підстави виникнення права податкової застави. Визначено статус та повноваження податкового керуючого. Розкрито правовий режим майна, яке перебуває у податковій заставі, обсяг прав платників податків на його використання, порядок узгодження операцій із заставленими активами. Вказано правові підстави припинення права податкової застави. Описано правовий механізм реалізації права податкової застави, вказано на його недоліки. Внесено пропозиції щодо удосконалення правового регулювання податкової застави для підвищення ефективності цього засобу з метою забезпечення належного виконання конституційного обов’язку зі сплати податків.

Ключові слова: конституційний обов'язок, податок, платник податків податковий обов'язок, податкова застава.

Резюме

Греца С.М. Налоговый залог как способ обеспечения исполнения конституционной обязанности по уплате налогов и сборов.

В статье освещаются правовые аспекты применения налогового залога как способа обеспечения конституционной обязанности по уплате налогов и сборов. Определено место обязанности по уплате налогов в системе конституционных обязанностей. Раскрыты основные способы обеспечения исполнения налоговой обязанности. Дано определение понятия налогового 
залога, раскрыта история становления этого института в законодательстве Украины. Приведены основания возникновения права налогового залога. Определен статус и полномочия налогового управляющего. Раскрыт правовой режим имущества, находящегося в налоговом залоге, показаны объем прав налогоплательщиков на его использование, порядок согласования операций с заложенными активами. Указаны правовые основания прекращения права налогового залога. Описан правовой механизм реализации права налогового залога, указано на его недостатки. Внесены предложения по совершенствованию правового регулирования налогового залога для повышения эффективности этого средства с целью обеспечения надлежащего выполнения конституционной обязанности по уплате налогов.

Ключевые слова: конституционный долг, налог, налогоплательщик налоговый долг, налоговый залог.

Summary

Svitlana Hretsa. Tax lien as a way to ensure the fulfillment of the constitutional obligation to pay taxes and fees.

The article highlights the legal aspects of using the tax lien as a means to ensure the constitutional obligation to pay taxes and fees. The focus is on the importance of proper implementation of constitutional obligations for the protection of human rights and the performance of state functions. An important place for tax liability in the system of constitutional obligations has been identified. The main ways of ensuring the fulfillment of the tax obligation have been revealed and the key role of such a way as tax lien has been emphasized. The concept of tax lien is defined and the history of formation of this institution in the legislation of Ukraine is revealed. The grounds for the emergence of the right of tax lien, the peculiarities of its documentation (registration) is presented. The status and powers of the tax manager about the description of the property in the tax lien, checks of its condition, etc. are determined. The article describes the legal consequences of non-compliance with the legal requirements of the tax manager, in particular the suspension in court of expenditure transactions on bank accounts, and in some cases - the use of administrative seizure of property. The author discloses the legal regime of property that is in tax lien, the scope of taxpayers' rights to use it, the content of legislative restrictions on the possibility of disposing of such property, the procedure for coordinating transactions with mortgage assets. The legal grounds for termination of the right of tax lien are indicated. The legal mechanism of realization of the right of the tax pledge, the order and sequence of the address of collecting on the pledged property is described. The author revealed the shortcomings of the legislation, in particular the long nature of the recovery in court. Proposals have been made to improve the legal regulation of the tax lien to increase the effectiveness of this instrument to ensure proper implementation of the constitutional obligation to pay taxes. In particular, it is proposed to provide the possibility of extrajudicial recovery of property that is in tax lien when the taxpayer has given written consent.

Key words: constitutional obligation, tax, taxpayer tax liability, tax lien.

DOI: 10.36695/2219-5521.4.2020.16

УДК 342.11 .5

\section{М.В. ГРОМОВЧУК}

Мирослава Володимирівна Громовчук, кандидат юридичних наук, доцент, доцент ДВНЗ «Ужгородський національний університет»*

ORCID: 0000-0003-2077-2342

\section{МЕЖІ ДОПУСТИМОГО ВТРУЧАННЯ ПРИ ПРОВЕДЕННІ БІОМЕДИЧНИХ ДОСЛІДЖЕНЬ СОМАТИЧНИХ ПРАВ ЛЮДИНИ}

Актуальність теми дослідження. Медичне дослідження за участі людини, з одного боку, активно стимулює прогрес у галузі біології та медицини, а з іншого, - містить у собі потенційну загрозу у для піддослідного. Воно супроводжується порушенням прав піддослідного на особисту недоторканність, свободу та автономію, самостійне розпорядження життям і здоров'ям, інформацію, повагу до честі й гідності. Зазначені фактори зумовлюють необхідність детального та чіткого регулювання процедури проведення біомедичних досліджень за участю людини в якості їх об'єкта.

У міру ускладнення суспільних взаємовідносин питання біомедичних досліджень нерідко стали розглядатися як складова частина медичного права - нової галузі, що поетапно формується в сучасній Україні. У зв'язку з цим автором було вивчено питання побудови системи права, а також проблеми комплексного правового регулювання проведення біомедичних досліджень, які отримали висвітлення в працях А. Билиці, П. Вітте, Н. Кашканової, О. Кашинцевої, С.Козодаєва, А. Концовенко, А. Куліша, Ю. Кундієва, С. Пустовіт, Е. Труханової та ін.

Мета даної публікації полягає в розробці наукового підходу щодо категорії «межі допустимого втручання при проведенні біомедичних досліджень соматичних прав людини».

Виклад основного матеріалу. Ефективне забезпечення конституційних прав і свобод людини і громадянина пов'язане $з$ необхідністю обмежень в їх реалізації. На сьогоднішній день науковці виділяють два поняття - «межі здійснення прав людини» та «обмежування здійснення прав людини». Так, зокрема, П. Рабі-

(C) М.В. Громовчук, 2020

* Myroslava Hromovchuk, Ph.D. in Law, Associate Professor, Associate Professor of Uzhhorod National University 